Helena Persson är doktorand i pedagogiskt arbete vid Umeå universitet. Hon har en bakgrund som ämneslärare i kemi och biologi och har undervisat i grundskolans senare år i de naturvetenskapliga ämnena. Hennes forskningsintresse handlar om lärarens projekt med ämnesintegrerad naturvetenskaplig undervisning, både inom de naturveteskapliga ämnena och mot skolans andra ämnen, i skolår 7 till 9.

Margareta Ekborg är docent i pedagogiskt arbete med inriktning mot naturvetenskapernas didaktik vid Umeå universitet. Hennes forskningsintresse rör frågor om sambandet mellan naturvetenskapliga kunskaper och andra faktorer för att förstå och kunna ta del i debatt i samhällsfrågor med naturvetenskapligt innehåll (SSI).

Anders Garpelin är professor i pedagogik med inriktning mot specialpedagogik. Hans forskningsintresse gäller etnografiska studier i klassrum och skolmiljö om vad mötet mellan pedagoger och elever betyder utifrån ett aktörsperspektiv. Särskilt fokuseras frågor om ledarskap och grupprocesser samt delaktighet och marginalisering som förutsättningar för lärande.

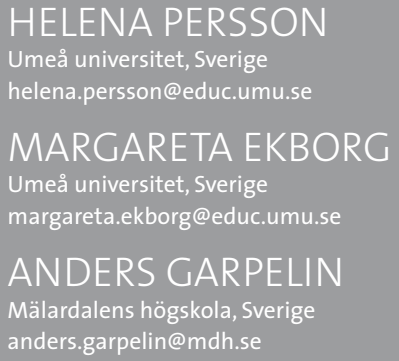

\title{
Ämnesintegrerad undervisning i naturvetenskap - Vad är det?
}

\begin{abstract}
Biology, chemistry and physics might be taught as separate subjects, but sometimes they are taught as combined with one another or with other subjects. Nationally and internationally the concept integrated science teaching lacks a uniform definition. To find out more about how practicing teachers define and perform integrated teaching, interviews were undertaken with five teachers, teaching science in school year 7 to 9 (age 13-16) in the Swedish compulsory school. Two ways of integrating science teaching were found; one combining the science subjects and one combining the science subjects with other school subjects. Results showed differences in the ways of teaching integrated science, in the interpretation of what the teachers meant by science integrating teaching and which obstacles and possibilities they saw. Visions about working with integrated science in the future and how these visions correspond to teacher's reality is also discussed.
\end{abstract}

\section{INLEDNING}

Den svenska grundskolan har sedan 1980 haft två läroplaner, Lgr 80 (Skolöverstyrelsen, 1980) och Lpo94 (Skolverket, 1994). Dessa har haft olika tyngdpunkt när det gäller ämnesintegrering i de naturvetenskapliga ämnena. Ämnesintegreringen mellan grundskolans ämnen var en viktig utgångspunkt i Lgr80 (Svingby, 1986). De naturvetenskapliga huvudmomenten delades in i tre teman: Människan, Naturen och människan samt Människans verksamhet och inte som tidigare ämnesvis. Innehållet i de naturvetenskapliga ämnena angavs som en helhet och inte separat för 
kemi, biologi och fysik. Enligt Andersson (1994) markerades det i Lgr 80 att det krävdes mer än traditionell ämnesundervisning för att uppnå de mål som fanns i grundskolan. Han poängterar dock att det inte sägs att undervisningen därmed i huvudsak skulle vara ämnesövergripande. Med Lpo 94 (Skolverket, 1994) skedde en förändring och det blev åter separata kursplaner för biologi, fysik och kemi, vilket kan ses som en strävan att skilja ämnena åt. I Lpo 94 finns några gemensamma mål att sträva mot och enskilda ämnesmål som eleven ska ha uppnått i femte respektive nionde skolåret. År 2000 (Skolverket, 2002) reviderades Lpo 94's kursplaner. De naturorienterande ämnena fick en gemensam kursplanetext som är mer omfattande än den tidigare. Den reviderade kursplanen kan ses som ett närmande till Lgr 80 då det uttrycks att: "Studier inom det naturorienterande ämnesområdet kopplas samman med kunskaper och uttrycksformer inom skolans andra ämnen" (Skolverket, 2002). Hur har dessa förändringar i kursplanernas innehåll influerat den ämnesintegrerade undervisning som sker i dagens svenska grundskola, särskilt den som baserar sig antingen på enbart de naturvetenskapliga ämnena eller i kombination med andra skolämnen?

\section{VAD INNEBÄR ÄMNESINTEGRERAD NATURVETENSKAPLIG UNDERVISNING?}

Ämnesintegrerad undervisning är ingen ny företeelse vare sig i Sverige (Svingby, 1986) eller internationellt (McComas \& Wang, 1998; Vars, 1991). Det finns många exempel på projekt runt om i världen med ambitionen att strukturera innehållet integrerat. Några exempel på grundskolenivå är PING, Practising Integration in Science Education (Black \& Atkin, 1996; Lang, 2000; Reinhold, 1999; Riquarts \& Hansen, 1998) i Tyskland, IS, Integrated Science (Rainey \& Miller, 1997) i Canada. Exempel på gymnasienivå är ANW Algemene Natuurwetenschappen (De Vos \& Reiding, 1999) i Nederländerna.

Ämnesintegrerad naturvetenskaplig undervisning kan ges olika innebörd. Gemensamt är, enligt Sjøberg (2005), att ordet integrerande ämnen används när separata ämnen presenteras i ett sammanhang. Begrepp som ämnesintegrerad, ämnesövergripande och tematisk förekommer som beteckning för denna form av undervisning (Lederman \& Niess, 1997). I internationell forskning finns det ingen enhetlig definition av ämnesintegrerad undervisning, integrated science (Berlin \& Lee, 2005; Czerniak, 2007; Czerniak, Weber, Sandmann \& Ahern, 1999; Davidson, Millar \& Metheny, 1995; Dressel, 1958a). Olika begrepp kan betyda samma sak och samma begrepp kan definieras på olika sätt. Antalet ingående ämnen varierar också liksom innehåll, processer och organisation (Beane, 1997; Czerniak et al., 1999; Davidson et al., 1995; Lederman et al., 1997; McComas et al., 1998; Vars, 1991). Lederman och Niess (1997) menar att detta skapar förvirring och begränsningar. Avsaknaden av ett gemensamt definierat begrepp försvårar möjligheterna att analysera och jämföra olika tillämpningar av ämnesintegrerad naturvetenskaplig undervisning (Beane, 1997; McComas \& Wang, 1998).

Svingby (1986) presenterade modeller för ämnesintegrerad undervisning i en tid då en gemensam kursplan för de naturorienterande ämnena, NO (Lgr 80) implementerades. Svingby poängterar att det är viktigt att skilja på den yttre organisationen av stoffet och den inre sammanställningen och bearbetningen som sker hos eleven. Hon väljer att tala om integration då det handlar om elevens inre process och samordning för att beskriva det yttre sambandet mellan ämnena. Utifrån Bernstein (1975), Halvorsen (1977) och Lund (1981) diskuterar Svingby (1986) samordningen utifrån två idealtyper som är varandras motpoler (Halvorsen, 1977). Den ena kännetecknas av separat ämnesläsning som innebär att ingen samordning finns. Den andra utgörs av en ämnesövergripande undervisning där total samordning råder. Mellan dessa lägen finns olika varianter där samordningens djup, bredd och frekvens varierar. Samordningens djup kan beskrivas utifrån hur ämnena är samordnade i olika nivåer (Halvorsen, 1977; Lund, 1981). På den första nivån, periodläsning, samlas varje ämne i ett block och läses under en bestämd tidsperiod innan nästa ämne tar över. Detta behöver inte innebära något som helst samband mellan ämnena men underlättar om man vill samordna ämnena. På nästa nivå skapas ett sammanhang inom olika avsnitt inom ämnet. 
Denna nivå har två former av integrering: successionsläsning och parallelläsning. Successionsläsning är en utveckling av nivå ett där utgångspunkten är en periodisering men innehållet i de olika ämnena samordnas till ett ämnesinnehålligt sammanhang. I parallelläsning har varje ämne sina timmar men ett gemensamt innehåll tas samtidigt upp i de ämnen som ingår. Fortfarande är det frågan om ämnesläsning men gränserna mellan ämnena är svagare. Enligt Lund (1981) är det först på den tredje nivån som man kan uppnå en integrering mellan ämnen. Det bygger på temaundervisning som bygger på ett för de olika skolämnena gemensamt tema som eleverna arbetar med. Samordningens bredd beskriver hur många ämnen som ingår vid samordningen och samordningsfrekvensen hur lång tid av den totala undervisningstiden som samordningen pågår (Svingby, 1986). I likhet med Svingby presenterar Fogerty (1991) olika former för integrering inom ämnen och mellan ämnen men tar även upp den integrering som sker hos individen. Fogarty (1991) ger en beskrivning av tio olika modeller för att integrera innehållet i undervisningen. Dessa modeller är uppdelade i tre grupper; integration inom enskilda discipliner, integration mellan olika discipliner och integration som sker inom en individ eller i samspel med andra individer. Hon anser att även om en modell är den som dominerar i en undervisning kan det ske flera olika modeller av integrering samtidigt.

I Australien genomfördes en undersökning om integrering av naturvetenskap, matematik och teknik med fokus på skolår 7 till 9. I de 16 medverkande skolorna fann forskarna elva olika typer av integrering men alla typer involverade inte naturvetenskap (Venville, Wallace, Léonie \& Malone, 1998). De fann att flera skolor hade mer än en form av integrering (jfr Fogerty, 1991). Däremot fann de inte på någon av skolorna en mer fullständig form av integrering där samtliga ämnen integrerades. Exempel på former av integrering som de fann var; tematisk tillämpning där lärarna hade ansvar för att deras undervisning var en del av ett tema eller teknikbaserat projekt. Andra former av integrering var tävlingar och lokala samhällsprojekt. Lärarna såg flera fördelar med den integrerade undervisningen, t.ex. att eleverna förstod de naturvetenskapliga och matematiska begrepp bättre när dessa tillämpades i teknikuppgifter satta i ett sammanhang. Å andra sidan fanns en oro hos lärarna över att strukturen kring fackämnena skulle falla sönder och att studenterna inte skulle få tillräckligt djupa ämneskunskaper av specialiserade lärare. Lederman et al (1997) anger att forskning indikerar att elever som har integrerad undervisning utvecklar sämre ämnesmässig förståelse. De menar att eleverna behöver goda grundläggande kunskaper för att få förutsättningar att arbeta med integrerade uppgifter eller tematiska perspektiv.

\section{MOTIV FÖR ÄMNESINTEGRERAD NATURVETENSKAPLIG UNDERVISNING}

Sjøberg (2005) presenterar tre typer av motiv för ämnesintegrerad undervisning: De ämnesmässiga motiven utgår från att de olika naturvetenskapliga ämnena är begreppsmässigt och innehållsmässigt lika och därmed med fördel bör integreras. De pedagogiska motiven tar sin utgångspunkt i betingelser för barns lärande men är också knutna till ämnenas samhälleliga betydelse. De organisatoriska motiven för ämnesintegrering kan t.ex. vara att det schematekniskt är enklare med ett ämne på schemat än flera.

Problemställningar tagna från vardagsföreteelser är sällan uppdelade efter ämnen och med vardagsproblem som utgångspunkt för undervisningen blir integrering naturlig. McComas och Wang (1998) menar att många ämnesintegrerade instruktioner använder sig av teman baserade på vardagsföreteelser, för att sammanföra enskilda ämnen. Användningen av 'real-world themes' det vill säga vardagsbaserade uppgifter i ämnesintegrerad undervisning hjälper eleverna att skapa positiva attityder till naturvetenskap. Motivation är enligt McComas och Wang en viktig psykologisk faktor. Österlind (2006), som studerat ämnesövergripande och undersökande arbetssätt kring elevers arbete med miljöfrågor, skriver att argumenten för ämnesintegrerad naturvetenskaplig undervisning handlar om motivation, samhällsnytta och förståelse. Att eleven får uppleva tillfredställelse, genom att utgångspunkten för deras arbete handlar om meningsfulla situationer, ökar motivatio- 
nen att lära sig (jfr även Beane, 1997; Nagel, 1996). Argumentet om samhällsnytta handlar om att ämnesövergripande studier sägs ge eleverna sådana kunskaper som de behöver i samhället.

I den svenska grundskolans kursplaner för de naturorienterande ämnena (Skolverket, 2002) uttrycks följande:

"I de naturorienterande ämnena återfinns tre aspekter, nämligen kunskap om natur och människa, kunskap om naturvetenskaplig verksamhet samt förmåga att använda sig av dessa kunskaper för att ta ställning $i$ värdefrågor, exempelvis miljö- och hälsofrågor."

Detta kunde tolkas som motiv för att organisera den naturvetenskapliga undervisningen som ämnesintegrerad. Detta återknyter till frågan i inledningen om vad lärare menar när de säger att de arbetar med ämnesintegrerad naturvetenskaplig undervisning.

\section{SYFTE OCH FORSKNINGSFRÅGOR}

Studiens syfte är att förstå vad lärare menar med ämnesintegrerad naturvetenskaplig undervisning och hur de bedriver denna undervisning.

Detta har utmynnat i följande forskningsfrågor:

- Hur beskriver lärare sin ämnesintegrerade undervisning?

- Vilka motiv har lärarna för att arbeta ämnesintegrerat?

- Vilka hinder och möjligheter ser lärarna med att arbeta ämnesintegrerat?

\section{MetOd}

För att uppnå syftet valdes att samla in data genom kvalitativa forskningsintervjuer (Kvale, 1997). Intervjuunderlaget testades och utvecklades i en pilotstudie. Intervjuerna inleddes med frågor om bakgrund, bl.a. hur länge lärarna arbetat, deras utbildning och vilka ämnen de undervisade i. Lärarna fick därefter beskriva hur de arbetade ämnesintegrerat med planering, undervisning och laborationer. Motiv, hinder, möjligheter och tillvägagångssätt utgjorde frågeområden i intervjuerna. Några generella slutsatser kan inte dras av de fem intervjuerna.

\section{Urval}

Inför intervjuerna kontaktades rektor med frågan om lärare som arbetade ämnesintegrerat i de naturvetenskapliga ämnena. Syftet var att rektor skulle välja ut vilka lärare som arbetar ämnesintegrerat. Rektorerna hänvisade i sin tur till lärarna. Alla lärare utom en valdes utifrån rektors rekommendationer. I studien ingår fem kvinnliga lärare som undervisar i NO-ämnena intervjuats. Alla arbetar på skolor där man arbetar från förskoleklass till skolår 9 (F-9 skolor).

\section{Genomförande och etik}

Intervjuerna var mellan 50 och 90 minuter långa och gjordes på plats vald av informanten. De spelades in och transkriberades ordagrant. Lärarna fick information kring studien och dess innehåll per telefon vid första kontakten, via ett skickat informationsbrev och samt vid intervjutillfället. De kunde när som helst meddela om de ville avbryta sitt deltagande i studien. Varje lärare namnges i artikeln med pseudonym (Vetenskapsrådet, 2008).

\section{Analys}

De transkriberade texterna studerades i sin helhet. Först delades texten upp utifrån vad samtalet handlade om. I nästa steg tolkades textens delar och en noggrann beskrivning av varje lärares berättelse gjordes. Grundläggande uppgifter sammanställdes, t.ex. utbildning, examensår och un- 
dervisande ämnen. Därefter anlades åter ett helhetsperspektiv på materialet genom att lyssna på de ursprungliga ljudfilerna parallellt med transkriberingarna och berättelserna. En mycket utförlig sammanställning gjordes utifrån de teman som vuxit fram vid analysen av materialet: inre/yttre drivkraft, arbetsform, ämnen som ingår vid integrering, betygsättning och allmän beskrivning. I denna sammanställning användes även begrepp från källor refererade till i litteraturgenomgången, såsom: ämnesmässiga motiv, pedagogiska motiv och lärares identitet (Sjøberg, 2005); graden av samordning samt dess djup, bredd och frekvens (Halvorsen, 1977; Lund, 1981; Svingby, 1986).

\section{Resultat}

Fyra av lärarna, Berit, Frida, Susanne och Ulla hade lärarutbildning i matematik-naturvetenskap skolår 4-9 medan den femte läraren, Anne, hade ämneslärarexamen med naturvetenskapliga ämnen. Deras yrkeserfarenhet som lärare varierade från fyra år till tjugoett år. Två av lärarna hade en annan yrkeskarriär bakom sig. Samtliga undervisade i skolår 7-9 och förutom naturvetenskap även i matematik och tre av dem undervisade dessutom i teknik.

\section{Hur beskriver lärarna sin ämnesintegrerade undervisning?}

De intervjuade lärarna hade flera former av undervisning. Två former av ämnesintegrerad naturvetenskaplig undervisning presenterades; ämnesintegrering inom de naturvetenskapliga ämnena och ämnesintegrering av naturvetenskapliga ämnen mot skolans andra ämnen. Inom de två formerna fanns flera olika tillvägagångssätt för att praktiskt genomföra den ämnesintegrerade naturvetenskapliga undervisningen.

Den första formen av ämnesintegrerad undervisning handlar om att undervisa de naturvetenskapliga ämnena som en helhet. Denna form av undervisning beskrivs i den ordinarie undervisningen av Anne och hos Ulla vid valda tillfällen. I Annes ordinarie undervisning sker en ständig ämnesintegrering inom NO-ämnena och teknik. Antalet naturvetenskapliga ämnen som ingår i ett tema varierar och ibland finns även inslag av slöjd tillsammans med undervisande slöjdlärare. Varje kurs har ett tema där temats innehåll har bestämts utifrån kursplanerna i de fyra ämnena kemi, biologi, fysik och teknik. Olika kurser har olika ämnestyngdpunkt med avseende på de naturvetenskapliga ämnena och teknik.

Ämnesintegrerat i det lilla är ett nyckelord för Ullas undervisning då hon väljer att undervisa de naturvetenskapliga ämnena ämnesintegrerat som ett avbrott i den ordinarie undervisningen. Ulla beskriver att hon vill använda naturliga samband för att skapa en helhet och berättar specifikt om två tillfällen i skolår 9. Vid det ena tillfället integreras matspjälkningen i biologi med avsnittet om fetter, proteiner och kolhydrater i kemi. Vid det andra tillfället sammanfogas biologins område ögat till fysikområdet ljuset.

"Äh... men det är alltså det man känner att det är naturligt att ta upp (paus) andra ämnesområden än just kanske kemiområdet då. När man jobbar med livsmedelskemi jamen då tar man upp matspjälkningen. Då man jobbar med ljuset ja då tar man upp om ögat. Att man inte tar upp det vid andra tillfällen utan just då $i$ samband då med det här området som man... där det passar in litegrann" (Ulla).

Ulla beskriver också i intervjun hur hon kopplar nya ämnesområden med tidigare ämnesområden som en slags repetition. Det innebär att hon sammanfogar tidigare undervisning inom ett naturvetenskapligt ämne exempelvis kemi med ett nytt område i samma ämne. Spontana vardagskopplingar, till exempel med hjälp av en tidningsartikel, initierade av henne eller av elever kan också ske i hennes undervisning men inte hos någon specifik åldersgrupp.

Den andra formen av ämnesintegrerad undervisning innebär att integrera naturvetenskap med skolans alla ämnen. Den används som ordinarie undervisning av Susanne och av Frida i en grupp 
av elever med behov av extra stöd och av Berit, Ulla och Anne som avbrott från den ordinarie undervisningen. I den elevgrupp med extra stöd som Frida undervisar arbetar hon med två eller tre av de naturvetenskapliga ämnena samtidigt. Det innebär att de naturvetenskapliga ämnena tillsammans med något av skolans andra ämnen, till exempel de samhällsvetenskapliga ämnena, undervisas kring ett tema. Susannes beskriver undervisningen på sin skola som ett ständigt ämnesintegrerat arbete som omfattar hela skolan. I det ämnesintegrerade området ingår olika ämnen i olika teman. Skolans modell handlar även om att de, lärare och elever, planerar undervisningen efter gemensamma mål och begrepp. I de fall det handlar om ett enskilt mål som bara finns i ett eller i flera av de naturvetenskapliga ämnena arbetar den ansvarige läraren själv kring detta.

\section{"Ähh... jag kommer att koppla in ljud ähh... det finns ett väldigt konkret mål inom ljud vilket gör att man lika gärna kan jobba med det i musiken, så att det är fysik, musik, svenska, SO och engelska som kommer att jobba tillsammans." (Susanne)}

Anne, Ulla och Berit använder tema som ett sätt att tillfälligt ämnesintegrera mot skolans andra ämnen. Berit berättar om ett avslutat energitema med parallellundervisning mellan de naturvetenskapliga och de samhällsvetenskapliga ämnena i skolår 9. Det innebar att varje lärare i fysik, kemi och biologi huvudsakligen gjorde en enskild planering men att viss gemensam planering förekom innan undervisningen startades på lektionerna i respektive ämne.

"Jag har mest varit med om är när vi har haft nior och vi har jobbat energi och miljö. (paus) $\ddot{A} h m n$... Och då har det varit mellan NO och SO då... mest (Paus) Ähmn... och då det gäller planering så vet ja inte så där, jag har inte så jättemycket planering, inte så mycket planeringstid tillsammans, jag och SO-lärar'n, det har det inte varit. Man har som mer, kanske har mer planerat för sig själv och så har man försökt föra ihop de olika planeringarna så..." (Berit)

\section{Vilka motiv har de för att arbeta ämnesintegrerat?}

Lärarna tog fram fem olika motiv för att arbeta ämnesintegrerat. Anne, Susanne, Ulla och Frida uttrycker ämnesmässiga motiv för den ämnesintegrerade naturvetenskapliga undervisningen. De menar att ämnesintegrerat arbete är ett roligt sätt att både undervisa och för eleverna att lära sig. Det handlar om att eleverna ska se helheten och på så sätt kan elevernas lust att lära sig väckas. Anne lyfter fram att en helhetssyn på kunskapen ska genomsyra undervisningen.

"Att naturvetenskapen är en helhet. Att det hänger ihop. Att vetenskaperna väldigt mycket går in $i$ varandra (paus) och man har nytta av den ena i den andra, och så där va." (Anne)

Eleverna ska se likheterna mellan olika ämnen och Anne, Susanne, Ulla och Frida vill att eleverna ska få en röd tråd i undervisningen. Ulla framhåller flera gånger under intervjun att hennes önskan är att det ska bli en röd tråd utifrån att eleverna ska se sambanden mellan de naturvetenskapliga ämnena men lyfter också en vardagsanknytning som ett motiv. Det är viktigt att eleverna kan placera in sig själva $\mathrm{i}$ ett naturvetenskapligt sammanhang.

Berit framhåller en annan aspekt på kopplingen till vardagen, ett samhällsnyttomotiv. Genom ämnesintegrering är det möjligt att ge eleverna demokratiska kunskaper för att kunna ta ställning i samhällsfrågor.

"Hmm... nja inte mer än att dom ska ha, fått en orientering $i$, ja som i höstas energi, vilka energiformer som finns å, för- och nackdelar å mmm..., ja så att dom har någon uppfattning $i$ den frågan. (Paus) Så att dom förstår att allting inte är av godo alla gånger...” (Berit)

Det fjärde motivet som Frida och Susanne lyfter är att den kunskap eleverna får ska vara användbar i deras vardag. För Frida handlar det om frågeställningar från det vardagliga livet där ett 
centralt mål är att eleverna lär sig att söka kunskap på olika sätt och där det resultatet är viktigare än själva processen. För Susanne är det själva processen under arbetets gång som framhålls som det viktiga och där slutprodukten är en del av flera i denna process.

"Ja, min högsta önskan är att eleverna lär sig sån kunskap som dom kan bära med sig i livet. Som dom kan ha nytta av den i sin vardag. (Paus) Byter dom däck, tvättar dom i en maskin, lagar dom mat, rengör dom saker, ähmn... Vad är det mer? Ja men... (Paus) Lika löser... ja allt som behövs för att dra nytta av i sin vardag." (Susanne)

I intervjuerna lyfts även olika organisatoriska motiv för att ämnesintegrera. Ett sådant motiv handlar om att kunna organisera undervisningen. Frida menar att i hennes elevgrupp med extra stöd är det viktigt att individanpassa undervisningen efter deras behov. Ämnesintegreringen ser hon som ett medel för att nå denna individanpassade undervisning där alla elever kan arbeta kring ett tema utifrån var de enskilda eleverna befinner sig kunskapsmässigt. Ulla lyfter ett annat syfte, nämligen att det är viktigt att undervisa i alla NO-ämnen och matematik i en klass för att få en relation till eleverna. Det är också är en fördel att undervisa eleverna under flera år för att sammankoppla tidigare arbetsområden med nya.

"För dom här niorna som jag har nu har jag träffat under tre år. Då kan jag, då kan jag tänka, prata med dom å säga: "Kom ni ihåg när vi gjorde de och de?". A alltså ta upp dom där trådarna å förhoppningsvis ähmn... kanske sammankoppla det med det jag jobbar med just då $i$ de bästa världar. Jomen litegrann så att nu... nu i åttan så gjorde vi det här med, med induktion och nu ska vi prata energier å alltså hur skapar vi då elektrisk energi. Och sånt där! Att man kan repetera litegrann och så ser man det $i$ ett vidare perspektiv på någotvis." (Ulla)

Ett annat organisatoriskt motiv handlar om var beslut fattas. Enligt Frida kan initiativet för att ämnesintegrerad undervisning även komma till efter beslut fattade på rektorsnivå eller högre beslutsnivå. I de fem intervjuerna framkommer att det funnits eller finns en vilja från rektor eller att det finns beslut fattade på instans över rektor om att skola ska arbeta ämnesintegrerat i någon form.

\section{Vilka är lärarnas visioner om ämnesintegrerad undervisning?}

Det finns i intervjuerna skillnader i lärarnas beskrivningar av sin ämnesintegrerade undervisning och i lärarnas visioner om vad ämnesintegrerad undervisning borde vara. Ullas visioner om ämnesintegrerad undervisning är en undervisning styrd av skolledning, där alla skolans ämnen bidrar. I denna undervisning kan man arbeta med två ämnen tillsammans under en lektion. Exempelvis kan texterna eller laborationsrapporterna i naturvetenskap används av undervisande lärare i svenska.

"Jomen att man finns där $i$ alla ämnen. Att jag skulle kunna gå in $i$ svenska... För att... Jag kan känna att svenska i NO också. Att lära sig å... å... läsa och skriva NO är ju också svenska så att visst skulle man kunna tänka sig att, att, att svenska läraren var med på NO timmarna och hjälpte till med att läsa och formulera sig på nåt sätt va? När man skriver labrapporter är det ju lika mycket svenska som någonting annat. Jamen att min NO skulle finnas då i engelskan å $i$ (paus) hemkunskapen, ja... Att den finns med på bilden. Ja men så! Att man hela tiden se... se NO:n i..." (Ulla)

Berit beskriver sina visioner om samarbete mellan alla skolans ämnen utifrån de mål skolan hade då den startades upp. Målet var ämnesövergripande undervisning där alla skolans ämnen skulle bidra. Fridas vision om ämnesintegrerad undervisning beskrivs utifrån hennes tidigare erfarenheter. Hon beskriver en undervisning där så många skolämnen som möjligt integreras kring ett tema. I Fridas vision används ett undersökande arbetssätt där eleverna själva ska finna sin kunskap. 
"Vi bröt ju allt! Det, problemet var ju att det var en stor skola. Det vi gjorde var att under tre veckor så, så jobbade vi bara tema på alla lektioner dom hade. I och för sig sprang dom ju runt på sina lektionssalar men dom jobbade ju med sitt tema hela tiden. Och det spela... och sen den läraren, det spelade ingen roll vilket ämne läraren hade utan den hade som en handledarroll kan man säga!” (Frida)

Susanne är den lärare som undervisar på det sätt som de tidigare lärarna beskriver sina visioner. På hennes skola sammanförs de olika ämnena så att det bildar en röd tråd kring inom ett gemensamt arbetsområde utifrån kursplanernas mål. Detta arbetssätt är under ständig diskussion och har arbetats fram under flera år. Också Anne beskriver en ständigt pågående ämnesintegrering, men då endast inom de naturvetenskapliga ämnena och teknik med ett visst inslag av de båda slöjdämnena. Här lyfts inga visioner fram om hur ämnesintegrerad undervisning borde se ut utan hon beskriver hur den redan befintliga ämnesintegreringen är under ständig förändring.

\section{Vilka möjligheter och hinder ser lärarna?}

Anne menar att det finns stora vinster med deras arbetssätt. Den största vinningen är ämnesmässig, att kunna koppla ihop de olika områdena i naturvetenskap, så att man se de stora sammanhangen.

"Så var det också kul,... (paus) ååå, man vinner det här, man vinner det stora sammanhanget på att integrera dom med varandra..." (Anne)

Nackdelen är att en del elever som tycker särskilt mycket om något av NO-ämnena och tycker att ett annat NO-ämne är svårt kan förlora sitt intresse för naturvetenskap. Det framkommer också att det finns svårigheter att göra gränsdragningar mellan ämnena i laborationsmoment, framför allt kemi och fysik. Vid ämnesintegrering är fördelen att läraren inte behöver fundera på till vilket ämne laborationen hör.

"Kanske kan man, kan man tänka att för dom som, för dom eleverna som, det finns ju dom som älskar biologi, och som hatar kemi och fysik... och då kan jag tänka att dom hade jag nog tänkt om jag hade varit deras biologilärare, och kemilärare, jag kunde kanske ha varit båda delarna... så kunde jag alltså ... de var liksom tydligare då så att dom kunde då få blomma ut. Dom var glada när dom kom till biologin. Det var kul! Och så var dom inte glada när dom kom till kemin för det var ju inte kul. Och då fick dom ha, och nu, risken finnas med dom som tycker att en del är väldigt svårt och en del är kul, att det blir lite...nja... det är inte så roligt med NO.” (Anne)

Ulla menar att vid ämnesintegrering måste man ta hänsyn till de förkunskaper eleverna har när de kommer till skolår 7. Det handlar om att ge grundläggande kunskaper för att i skolår 9 kunna koppla samman ämnena. Bristande naturvetenskapliga kunskaper i skolår 7 gör det svårt att hinna med allt innehåll i ämnena. Hon arbetar därför mer ämnesintegrerat i skolår 9 då eleverna har bättre baskunskaper.

Det finns skilda åsikter bland lärarna huruvida betygsättningen begränsar möjligheterna att arbeta ämnesintegrerat. Anne som i stora delar arbetar ämnesintegrerat menar att eleverna i skolår 9 börjat få en uppfattning om skillnaderna i ämnena och därför kan samlingsbetyg sättas i skolår 8 och separata betyg i de olika NO-ämnena i skolår 9. Hon tycker att det är bättre för de elever som presterar olika i de naturvetenskapliga ämnena att sätta separata betyg i skolår 9. Det ger eleverna möjlighet att få ett högre betyg i något av de naturvetenskapliga ämnena. Susanne och Frida menar istället att samlingsbetyg bättre följer helhetstanken med ämnesintegrering. Frida resonerar att ett samlingsbetyg stämmer överens med både synsättet om ämnesintegrerad undervisning och elevdelaktighet. Enligt henne möjliggör ämnesintegrerad undervisning en större delaktighet för 
eleverna då det är lättare att individanpassa undervisningen i undervisningsgrupper med många olika behov. Med ämnesintegrerad undervisning får eleverna en möjlighet att arbeta tillsammans även om de är på olika nivåer och har olika förutsättningar med en roligare undervisning som resultat.

Detta står i kontrast till Fridas resonemang om att ämnesintegrerad undervisning är ett medel att använda sig av vid undersökande arbetssätt. Det finns en problematik med att elever har olika kapacitet och hur de gynnas av ett undersökande arbetssätt. För de elever som har svårigheter att ta ansvar för sitt eget lärande är de viktigt att det finns flera vuxna som stödjer dessa elever för att de inte ska misslyckas. Det är en undervisningsform som kräver vuxnas handledning enligt henne. De svaga elever som behöver struktur ta tröttnar fort och misslyckas medan de motiverade eleverna känner sig lyckade.

Organisatoriskt nämns flera olika faktorer som begränsar eller hindrar ämnesintegrerad undervisning. Det handlar om avsaknaden av specifika läromedel, bristen på klassuppsättningar av NOlitteratur, schematekniska problem med lärarschema, elevschema och salschema och bristen på tillräckligt utrustade NO-salar.

"Det går ju inte, det blir så besvärligt när man ska göra det med, det blir så många kockar inblandade och schemaändringar å sånt där så... Schemat är man inte och rör $i$ så mycket för då blir det så där att då måste man komma överens med dom andra lärarna om man ska ämnesövergripande. Att vi gör det här temat och då får dom jobba med samma sak på din lektion här också. Plus att du måste ha, dom, dom måste ju vara intresserade av det. Vissa är lärare är intresserade och vissa är inte."(Frida)

En annan faktor är personalbrist. När skolan där Berit arbetar startades fanns ambitionen att arbeta ämnesintegrerat. Av organisatoriska skäl kring schemaläggning föll ambitionen att undervisa ämnesintegrerat då skolledning och lärare ansåg att det behövs fler lärare vid ämnesintegrerad undervisning. Sådana utökade resurser fanns inte att tillgå. Idag är undervisningen organiserad i blockläsning. Tiden är också en begränsande faktor och det finns en oro för att inte hinna undervisa de områden som eleverna ska ha med sig.

För att kunna genomföra organisatoriska förändringar framhålls vikten av kollegialt stöd, från både kollegor och skolledning. Samarbetet mellan lärare är en viktig faktor för att man ska orka arbeta ämnesintegrerat eftersom detta arbetssätt kräver mer än traditionell ämnesundervisning enligt de fem intervjuade lärarna. Att arbeta tematiskt kräver att alla lärare hjälper till och strukturerar undervisningen. Detta skulle vara trevligt enligt Ulla. Om lärarna samarbetar och planerar tillsammans medför det planeringsvinster och ett roligt sätt att arbeta.

"Därför att du ska ju, dels ska du samarbeta med alla kollegor som har olika ämnen. Å så måste du hitta, hitta knytpunkter för att... knytpunkter $i$ alla ämnena under det här temat. $\AA$ så... å samtidigt eleverna när man gör på det sättet friare att välja utifrån egna erfarenheter, egna... precis som det står i Lpo-94. Att dom ska var mer delaktiga i undervisningen. Det blir dom ju. Helt klart!" (Frida)

Anne menar att samarbete mellan naturvetenskapslärarna på skolan är en förutsättning för det arbetssätt som de har. NO-lärarna på skolan samplanerar, men inte genom att de har avsätter tid för detta, utan de har istället ständiga, spontana möten med varandra då de ger eller får synpunkter på det som var planerat i de olika NO-kurserna.

Frida säger att idag arbetar man inte längre ämnesintegrerat på skolan i den ordinarie undervisningen, då hon upplever att sådan undervisning tar mer kraft från personalen. Möjligheter finns 
ändå att arbeta tematisk i hennes klass, eftersom hon har eleverna i alla NO-ämnen. Resonemanget om, varför hon inte arbetar i temaform då möjligheten finns, handlar om att de andra lärarna inte arbetar så och att hon inte vill göra det själv utan ha någon att samarbeta med. Kollegorna på skolan är trötta och orkar inte. Dessutom påverkas betygsättningen. I intervjuerna framkommer de möjligheter lärarna ser med den ämnesintegrerade undervisning de beskriver men också svårigheter som i vissa fall också gör att undervisningen inte går att genomföra även intentionerna var så från början.

Tabell 1 är en sammanställning av den ämnesintegrerade undervisningen som presenterades. Ulla, Berit och Fridas ordinarie undervisning finns inte med i tabellen då den inte kan räknas som ämnesintegrerad undervisning utan är periodiserad och uppdelad i kemi, biologi och fysik. Med periodiserad menas att lärarna undervisar kemi, fysik och biologi i ett bestämt antal veckor. Periodernas längd mellan lärarna varierar.

Den naturvetenskapliga undervisningen hos de fem intervjuade lärarna. Tabellen är uppdelad efter form av undervisning och om denna form har karaktären av ordinarie undervisning eller som ett avbrott av den ordinarie undervisningen hos de fem lärarna.

\begin{tabular}{|l|c|c|c|c|c|}
\hline & Anne & Susanne & $\begin{array}{c}\text { Frida stöd- } \\
\text { grupp }\end{array}$ & Ulla & Berit \\
\hline $\begin{array}{l}\text { Ämnesintegrering: inom } \\
\text { NO-ämnena }\end{array}$ & $\mathrm{X}$ & & & $\mathrm{X}$ & \\
\hline $\begin{array}{l}\text { Ämnesintegrering: NO } \\
\text { mot skolans andra ämnen }\end{array}$ & & $\mathrm{X}$ & $\mathrm{X}$ & & $\mathrm{X}$ \\
\hline $\begin{array}{l}\text { Ämnesintegrering som } \\
\text { ordinarie undervisnings- } \\
\text { form }\end{array}$ & $\mathrm{X}$ & $\mathrm{X}$ & $\mathrm{X}$ & & \\
\hline $\begin{array}{l}\text { Ämnesintegrering som } \\
\text { avbrott från den ordinarie } \\
\text { undervisningen }\end{array}$ & & & & $\mathrm{X}$ & $\mathrm{X}$ \\
\hline
\end{tabular}

\section{Sammanfattning}

I studien fann vi två former av ämnesintegrerad undervisning, ämnesintegrering inom de naturvetenskapliga ämnena och ämnesintegrering av de naturvetenskapliga ämnena mot skolans andra ämnen. Lärarna berättar om de hur de går tillväga då de arbetar ämnesintegrerat. Den tid av den totala undervisningstiden som de fem lärarna använder för att ämnesintegrera skiljer sig åt likaså tolkningen av vad ämnesintegrerad undervisning är.

Anne beskriver en ständig ämnesintegrering inom de naturvetenskapliga ämnena utifrån arbetsområden med olika teman. Som avbrott mot denna ordinarie undervisning sker ibland teman mot skolans andra ämnen. Motivet för att arbeta ämnesintegrerat med de naturvetenskapliga ämnena och teknik är ämnesmässiga, att ge eleverna en helhetssyn på naturvetenskapen. En förutsättning för detta arbetssätt är samarbetet mellan de lärare som undervisar i de naturvetenskapliga ämnena. Ulla undervisar i sin ordinarie undervisningsform de naturvetenskapliga ämnena separat men använder ämnesintegreringen inom de naturvetenskapliga ämnena som ett avbrott i den separata ämnesundervisningen. Motivet för detta är att hitta naturliga samband som ger eleverna helhetssyn på kunskapen. De främsta hindren är av organisatorisk art och svagt stöd från kollegor. 
Susanne berättar om en ständig ämnesintegrering av ett eller flera av de naturvetenskapliga ämnena mot skolans andra ämnen. För Susanne handlar det om att ge eleverna en helhetssyn på kunskapen och att den kunskap eleverna få ska vara användbar i deras vardag. Hon betonar att slutresultatet är en del i elevernas process att söka kunskap. Samarbetet mellan lärare och elever vid planering av arbetsområdet är ett viktigt moment i ämnesintegreringen. Frida har separat ämnesundervisning i de flesta av sina grupper utom i den grupp av elever som behöver extra stöd. I den gruppen undervisar hon de naturvetenskapliga ämnena integrerat mot skolans andra ämnen. Det handlar om att ge eleverna ett helhetsperspektiv, lära sig söka efter kunskap och att kunna individanpassa undervisningen. Frida ser samarbete med kollegor som den vikigaste för att orka arbeta ämnesintegrerat. Berit arbetar oftast med separat ämnesundervisning. Ämnesintegreringen handlar om enstaka teman mot skolans andra ämnen, främst de samhällsvetenskapliga ämnena. Man vill ge eleverna en orientering utifrån temat så eleverna kan ta ställning i aktuella frågor. De begränsningar som hon uttrycker är av organisatorisk karaktär.

\section{DiskUsSiON}

Beane (1997) menar att ämnesintegrering har blivit populärare under 1990-talet och att synen på ämnesintegrerad undervisning bottnar i politiska värderingar, synsätt på för vem och till vad kunskapen är till för. Han lyfter fram flera faktorer som orsak till det ökade intresset för ämnesintegrering, bland annat att målformuleringar om att eleverna ska lära sig att tillämpa kunskap och inte bara memorera. Det framkommer i denna studie att det finns svårigheter med ämnesintegrerad undervisning. De finns en föreställning om att ämnesintegrerad undervisning är en undervisning där ämnesgränserna suddas ut samtidigt som kravet finns om att målen i de enskilda ämnena ska uppfyllas. Svårigheter kommer också fram i samband med betygsresonemanget. Dilemman i att sätta betyg upplevs framför allt då man arbetar ämnesintegrerat men sätter separata betyg i de i ämnena. Separata betyg upplevs strida mot helhetstanken som lärarna lyfter som motiv för ämnesintegrerad undervisning. När gränserna mellan ämnena suddas ut försvårar det för läraren att se vilka kunskaper som tillhör respektive ämne.

Olika synpunkter finns även om vad som är viktigt i en ämnesintegrerad undervisning där man använder undersökande arbetssätt. I studien uttrycker en av de intervjuade att själva målet är det viktiga medan en annan anser att det är själva processen, det vill säga sättet att söka kunskap, som är det centrala. Det finns i studien en uttalad tanke om att ämnesintegrerad undervisning också innebär undersökande arbetssätt vilket även annan forskning visar (Lederman et al., 1997, Svingby, 1986; Österlind, 2006). Är en undervisning baserad på undersökande arbetssätt, det vill säga en process där eleverna söker kunskap, något som är knutet till ämnesintegrerad undervisning eller går det alltid att ämnesintegrera oavsett val av arbetssätt? Det verkar som att hos dessa lärare är ämnesintegreringen ett medel att uppnå ett undersökande arbetssätt.

Ordet integrering innebär enligt Sjøberg (1995) att man sätter in fakta, kunskaper och processer i ett sammanhang. Dressel (1958 a; 1958 b) menar att integrering är en ständig inre process, som troligen är unik för varje individ, där erfarenheterna organiseras och skapar mening. Denna process kan bara fortgå genom upplevelser som främjar denna process. Beane (1997) menar att en integrerad undervisning i skolan innehåller mer än att koppla samman enskilda ämnen till ett tema. Det innefattar även att integrera elevernas erfarenheter i undervisningen, en social integrering med syfte att öka elevernas medverkan i planering och att tillsammans utarbeta en studieplan. Detta innebär att endast en skola i denna studie har vad han menar en undervisning som följer dessa kriterier. Men måste ämnesintegrering innebära att fakta, kunskaper och processer integreras samtidigt? I denna studie ser vi hos den lärare som undervisar de naturvetenskapliga ämnena som en helhet, att processer inte behöver innebära ett undersökande arbetssätt utan att de naturvetenskapliga processerna sätts i ett gemensamt sammanhang. 
Studien visar också att varje lärare beskriver flera olika sätt som de ämnesintegrerar på även om ett sätt dominerar. Detta överensstämmer med vad Fogerty (1991) som menar att även om en form av ämnesintegrering dominerar i en undervisning kan det förekomma andra former samtidigt. En lärare säger att de arbetar med teman på skolan men kopplar inte detta till den ämnesintegrerade undervisningen även om de naturvetenskapliga ämnena ingår. I en annan intervju nämns ämnesintegrerad undervisning i förbifarten och att det används i specialpedagogiskt syfte. Detta förstärker bilden av mångtydighet som begreppet ämnesintegrerad naturvetenskaplig undervisning har. I lärarnas beskrivningar framkommer också visioner om hur de skulle vilja arbeta ämnesintegrerat. Lärarna i studien lyfter visioner om hur "riktig" ämnesintegrerad naturvetenskaplig undervisning ska vara. Det handlar om den ämnesintegrering där alla skolans ämnen ingår och man arbetar kring ett gemensamt tema. Det är också en form av ämnesintegrerad undervisning som Venville et al. (1998) inte hade funnit i sin undersökning men som återfanns i vår studie. Kan visionen hindra lärarna att se att de faktiskt både ämnesintegrerar idag och har möjlighet att göra det? De fem lärarna uttryckte att de hade en önskan att arbeta ämnesintegrerat, men det framgick också att flera av dem inte såg sina möjligheter att förverkliga sina tankar och idéer. Vad är då en lyckad ämnesintegrering? Utifrån denna studie kan sägas att de två lärare som arbetar större delen av sin tid ämnesintegrerat, en inom de naturvetenskapliga ämnena och den andra mot skolans alla ämnen, var nöjda med sitt sätt att arbeta.

Olika synpunkter finns också bland lärarna om när det är lämpligast att ämnesintegrera. En åsikt är att det är bättre att ämnesintegrera i skolår 9 då eleverna har fått tillräckliga med grundläggande kunskaper och ser därför ser sambanden bättre. Detta är något som Lederman et al. (1997) poängterar som en viktig förutsättning för lyckade ämnesintegreringar. Enligt dem är det viktigt att eleverna har goda grundläggande kunskaper då de arbetar ämnesintegrerat för att inte utveckla sämre ämnesmässig förståelse. Den andra åsikten som lyfts fram i denna studie är, att ju äldre eleverna blir desto bättre uppfattning har de om vilka kunskaper som tillhör kemi, biologi respektive fysik, och därför bör man börja ämnesintegrera i skolår 7 så att de ska få ett helhetsperspektiv på naturvetenskapen. Allt eftersom elevernas kunskaper ökar blir det svårare hålla ihop de naturveteskapliga ämnena då de blir mer och mer specialiserade kunskapsmässigt.

Det viktigaste motivet för de intervjuade lärarna att ämnesintegrera är det ämnesmässiga argumentet att ge eleverna en helhetssyn på kunskapen (Sjøberg, 2005) och ett samband mellan ämnen. Millar (1996) påpekar att den största delen av skolans elever inte kommer att läsa vidare inom det naturvetenskapliga fältet. Dessa elever behöver inte djupa kunskaper för en senare spetskompetens utan en naturvetenskap förankrat i deras dagliga liv. En önskan om att den kunskap som eleverna får ska vara användbar i elevernas vardag uttrycks i studien. Ett annat motiv för dem är det pedagogiska argumentet (Sjøberg, 2005), att ge eleverna verktyg för framtiden genom undersökande arbetssätt, där undervisningen ska utgå från elevernas egna frågeställningar och där eleverna själva kan lära sig att hitta kunskaper. Ett sådant sätt att arbeta kan skapa problem för elever med svårigheter med sitt lärande. De behöver tillgång till vuxna som kan stötta dem för att de klara av ett undersökande arbetssätt. Detta står i kontrast till syftet med ämnesintegrerad undervisning som en möjlighet till att individanpassa undervisningen då det finns elever med olika behov.

Hos de lärare som deltog i studien var det viktigaste hindret för att kunna arbeta ämnesintegrerat av organisatorisk karaktär. För att arbeta ämnesintegrerat behöver lärarna stöd av varandra och de vill kunna samarbeta med andra kollegor som är intresserade av att arbeta integrerat. Stöd av skolledningen är också viktigt. Skolledningen har möjlighet att undanröja en del av de organisatoriska hindren. Beane (1997) menar att skolorna inte är anpassade för ämnesintegrerad undervisning. Det framgår av intervjuerna att det kräver mer av lärarna att arbeta ämnesintegrerad undervisning än då ämnena undervisas separat. Frågan är om denna typ av undervisning kräver mer eller om det är så att de intervjuade pedagogerna är ovana att arbeta så och därmed behöver mer förberedelse. 
Intressant är att då ämnesintegrerad undervisning beskrivs som en undervisningsform där alla skolans ämnen involveras uttrycks det att initiativet till detta ska komma eller kommer från skolledning eller att beslut fattas över skolledningen. Då ämnesintegrerad undervisning beskrivs som integrering inom de naturvetenskapliga ämnena nämns inte skolledning. Här är utgångspunkten av en annan karaktär, en egen önskan att hitta nya sätt att presentera naturvetenskapen. Detta resultat är tänkvärt särskilt om ämnesintegrerad undervisning samtidigt utformas på ett sätt, men att det finns en vision om en ämnesintegrering där alla ämnen ingår. Det framkommer också i denna studie att ämnesintegrerad undervisning inte alltid är själva målet utan kan vara ett medel för att uppnå ett annat syfte t.ex. att kunna arbeta med undersökande arbetssätt och också som ett medel för att lättare kunna individanpassa undervisningen $\mathrm{i}$ heterogena undervisningsgrupper.

Även om inga generella slutsatser kan tas utifrån denna studie ges en indikation på att hur en lärare ämnesintegrerar de naturvetenskapliga ämnena är en sak och vad den personen menar med denna undervisning kan vara något annat. Om lärare och/eller skolledning har som motiv att undervisa ämnesintegrerat inom de naturvetenskapliga ämnena eller mot skolans andra ämnen är det viktigt att lärare och skolledare tillsammans klargör vad man menar med ämnesintegrering och vad det är man vill åstadkomma. Är ämnesintegreringen det huvudsakliga motivet eller är det ett medel för att åstadkomma något annat? Denna studie ger även en indikation om vikten av samarbete och kollegialt stöd vid ämnesintegrerad undervisning.

Studiens syfte är att förstå vad lärare menar med ämnesintegrerad naturvetenskaplig undervisning och hur de bedriver denna undervisning. Studien visar på en komplexitet när det gäller den ämnesintegrerade naturvetenskapliga undervisningen både när det gäller vad man menar när man säger att man arbetar ämnesintegrerat inom naturvetenskap och också vilka förutsättningar som finns för att kunna arbeta på detta sätt. Studien lyfter fram intressanta frågor att gå vidare med. Hur ser lärarens projekt ut i klassrummet när läraren undervisar ämnesintegrerat? Hur uppfattar eleverna ämnesintegrerad undervisning?

\section{Ett varmt tack till docent Sylvia Benckert, Umeå universitet, för noggrann läsning och värdefulla kommentarer.}

\section{REFERENSER}

Andersson, B. (1994). Nr 10. Om kunskapande genom integration. NA-spektrum. Göteborg: Institutionen för ämnesdidaktik, avdelningen för naturvetenskap.

Beane, J. A. (1995). Curriculum integration and the disciplines of knowledge. Phi Delta Kappa, 76(8), 616-622.

Beane, J. A. (1997). Curriculum integration. Designing the core of democratic education. New York: Teachers College Press.

Berlin, D. F. \& Lee, H. (2005). Integrating science and mathematics education: Historical analysis. School Science and Mathematics, 105(1), 15-24.

Bernstein, B. (1975) Class, codes and control. London and Boston: Routlege \& Kegan Paul.

Black, P. \& Atkin, J. M. (1996). Changing the subject. Innovations in science, mathematics and technology education. London and New York: I samarbete med OECD, Routledge.

Czerniak, C. M. (2007). Interdisciplinary science teaching. In S. K. Abell \& N. G. Lederman (Eds.), Handbook of Research on Science Education (s. 537-559). New Jersey London: Lawrence Erlbaum Associates.

Czerniak, C. M, Weber Jr., W. B., Sandmann, A. \& Ahern, J. (1999). A literature review of science and mathematics integration. School Science \& Mathematics 99(8), 421-430. 
Davidson, D. M., Miller, K. W., Metheny, D. L. (1995). What does integration of science and mathematics really mean? School Science \& Mathematics 95(5), 226-230.

De Vos, W. \& Reiding, J. (1999). Public understanding of science as a separate subject in secondary schools in the Netherlands. Interantional Journal of Science Education 21(7), 711-719.

Dressel, P. L. (1958 a). The meaning and significance of integration. In N. B. Henry (Ed), The integration of educational experiences. The fifty-seventh yearbook of the national society for the study of education (s.3-25). Illinois: The National Society for the Study of education.

Dressel, P. L. (1958 b). Integration: an expanding concept. In N. B. Henry (Ed), The integration of educational experiences. The fifty-seventh yearbook of the national society for the study of education (s.251-263). Illinois: The National Society for the Study of education.

Fogerty, R. (1991). Ten ways to integrate curriculum. Educational Leadership 49(2), 61-65.

Halvorsen, T. (1977). Ungdomsskole uten fag? Samfunnsfag i nye former. Oslo: Universitetsforlaget.

Kvale, S. (1997). Den kvalitativa forskningsintervjun. Lund: Studentlitteratur.

Lang, M. (2000). Mediated exchange and reflective collaboration: a model of science teaching development. Teachers and Teaching: theory and practice 6(1), 9-22.

Lederman, N. G. \& Niess, M. (1997). Integrated, interdisciplinary, or thematic instruction? Is this a question or is it questionable semantics? School Science and Mathematics 97(2), 57-58.

Lund, E. (1981). Samfunnsfag I praksis. Håndbok for laereren. Lommerdalen: Aschehoug.

McComas, W. F. \& Wang, H. A. (1998). Blended science: the rewards and callenges of integrating the science disciplines for instruction. School Science and Mathematics 98(6), 340-348.

Millar, R. (1996). Towards a science curriculum for public understanding. School Science Review 77(280), 7-18.

Nagel, N. G. (1996). Learning through real-world problem. The power of integrative teaching. Thousand Oaks, CA: Corwin Press.

Rainey, L. \& Miller, R. G. (1997). Integrated science. Science Scope (20), 60-61.

Reinhold, P. (1999). Case studies of teachers' reflective practice within the developmental research project PING. Journal of Curriculum Studies 31(5), 545-570.

Riquarts, K. \& Hansen, K-H. (1998). Collaboration among teachers, researchers and inservice trainers to develop an integrated science curriculum. Journal of Curriculum Studies 30(6), 661-676.

Sjøberg, S. (2005). Naturvetenskap som allmänbildning - en kritisk ämnesdidaktik. Lund. Studentlitteratur.

Skolverket (1994). Läroplan för det obligatoriska skolväsendet, förskoleklass och fritidshemmet, Lpo 94. Stockholm: Fritzes.

Skolverket (2002). Kursplaner och betygskriterier 2000. Grundskolan. Stockholm: Fritzes.

Skolöverstyrelsen (1998). Läroplan för grundskolan, Lgr 80. Stockholm: Liber Utbildnings Förlaget.

Svingby, G. (1986). Integration eller ämnesläsning - en fråga om kunskapsyn. I J. Naeslund, (Red.), Kunskap och begrepp. Centrala motiv $i$ våra läroplaner. Stockholm: Liber Utbildnings Förlaget.

Vars, G. F. (1991). Integrated curriculum in historical perspective. Educational Leadership 49(2), 14-15.

Venville. G., Wallace, J., Léonie, J. R. \& Malone, J. (1998). The integration of science, mathematics, and technology in a discipline-based culture. School Science and Mathematics 98(6), 294-302.

Vetenskapsrådet (2002). Forskningsetiska principer inom humanistisk-samhällsvetenskaplig forskning. Vetenskapsrådet. http://www.vr.se/download/18.6b2f98a910b3e260ae28000360 /HS_15.pdf

Österlind, K. (2006). Begreppsbildning i ämnesövergripande och undersökande arbetssätt. Studier av elevers arbete med miljöfrågor. Stockholm: Pedagogiska institutionen, Stockholms universitet. 